\title{
Palatability of cat food with sodium pyrophosphate and yeast extract
}

\author{
Palatabilidade de rações de gatos com pirofosfato de sódio e extrato de levedura
}

\author{
Rúbia Tabachi de Oliveira ${ }^{\mathrm{I}}$ Douglas Haese $^{\mathrm{I}^{*}}$ João Luís Kill ${ }^{\mathrm{I}}$ Anderson Lima ${ }^{\mathrm{II}}$

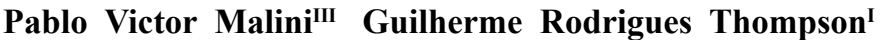

\section{ABSTRACT}

Cat food formulation should not only meet the animal's nutritional needs, but also take into account food attractiveness. Our aim was to assess the palatability of food coated with sodium pyrophosphate and yeast extract, alone or in combination, and 20 adult cats were used in a two-bowl preference test. The preference for the experimental foods was tested by external application of sodium pyrophosphate $(0.3 \%)$, yeast extract $(0.2 \%)$, and a blend $(0.5 \%)$ containing pyrophosphate and yeast extract in a same basal diet. In the present study, the cats showed preference for the blend $(0.5 \%)$ containing sodium pyrophosphate and yeast extract.
\end{abstract}

- NOTE
Key words: additives, nutrition, palatability, preference.

\section{RESUMO}

A formulação de rações para gatos deve não só satisfazer as necessidades nutricionais desses animais, mas também levar em conta a atratividade do alimento. Nosso objetivo foi avaliar a palatabilidade de rações contendo pirofosfato de sódio e extrato de levedura, isoladamente ou combinados, e foram usados 20 gatos adultos em testes de preferência pelo confronto direto entre duas rações (two-bowl test). As rações experimentais foram obtidas pela aplicação externa de uma mesma dieta basal de pirofosfato de sódio (0,3\%), extrato de levedura (0,2\%) e uma mistura $(0,5 \%)$ contendo pirofosfato de sódio e extrato de levedura. No presente estudo, os gatos mostraram preferência pela mistura $(0,5 \%)$ contendo pirofosfato de sódio e extrato de levedura.

Palavras-chave: aditivos, nutrição, palatabilidade, preferência

Food palatability is a combination of sensory, physical, and chemical characteristics such as aroma, taste, shape, moisture, and nutritional value. In addition, physical characteristics such as temperature and texture have also an important role in food preference. Cats prefer food at room temperature, dry and crunchy kibbles, and shapes that facilitate apprehension and incision (BRADSHAW et al., 1996; NRC, 2006).

Unlike dogs' preference, aroma alone does not appear to exert major influence on food preference by cats. Furthermore, olfactory acuity is diminished with ageing, adverse weather conditions, and drug use (ZAGHINI \& BIAGI, 2005). Conversely, cat's taste, which is based on the carnivore pattern, has a pronounced effect on food preference; however, with further specialization. This can be explained in terms of more specific nutritional requirements (BRADSHAW, 2006).

Taste information can be transmitted via four cranial nerves, but only the facial nerve has been investigated in detail in cats (BRADSHAW, et al., 1996). In the facial nerve, there are receptor units (amino acids, acid, and " $x$ " units) that can positively or negatively respond to stimuli (discharges) generated by amino acids, nucleotides, sugars, sodium ion, phosphoric acid, sodium chloride $(\mathrm{NaCl})$, and potassium chloride $(\mathrm{KCl})$. According to ZAGHINI \& BIAGI (2005), the most abundant units are responsive to some amino acids, and cats respond positively to proline, cysteine, ornithine, lysine,

\footnotetext{
IPrograma de Pós-graduação em Ciência Animal, Universidade Vila Velha (UVV), 29102-920, Vila Velha, ES, Brasil. E-mail: douglas.haese@uvv.br. "Corresponding author.

IIAlltech do Brasil, São Pedro do Ivaí, PR, Brasil.

IIINutriave Alimentos, Viana, ES, Brasil. 
histidine, and alanine, which are described as "sweet" by humans. Conversely, cats reject the "bitter" amino acids such as arginine, isoleucine, phenylalanine, and tryptophan, which inhibit these units.

Cats prefer foods containing lipids of vegetable or animal origin, hydrolyzed proteins, and animal-derived proteins found in red meat and liver (ZAGHINI \& BIAGI, 2005). The Maillard reaction that occurs during kibble extrusion also contributes to improve palatability, especially in containing vegetable origin food products such as soybean and corn meal. Cats have aversion to flavor of products containing medium-chain triglycerides, and are not stimulated by sugars (MACDONALD et al., 1984).

The search for increasingly palatable food has encouraged new researches to develop ingredients or additives, such as phosphorus compounds and yeast extract, which can positively stimulate the taste receptor units. Phosphorus based compounds, such as phosphoric acid, are used in cat food preparation to both prevent formation of struvite stones and promote oral health. However, other benefits, such as improvement in food palatability, can be obtained by including these compounds in cat food. According to BRAND \& BRYANT (2012), palatability improvement obtained with the use of phosphorus based compounds is probably due to their interaction with acid receptor units in the cat.

Yeast extract, which is obtained by enzyme extraction of the Saccharomyces cerevisiae cellular content is another food palatant. Yeast extract has nutrients, such as proteins, peptides, nucleotides, and free amino acids (especially rich in alanine, lysine, and glutamic acid), which are able to stimulate palatability as they stimulate amino acid receptor units. TESHIMA et al. (2007) observed improved palatability of dog food by supplementing the mass with yeast extract $(2 \%)$ before the extrusion process. However, OGOSHI et al. (2014) demonstrated that cats had reduced palatability after supplementation with yeast extract $(1.5 \%)$ over dry diet mixed with moist diet.

Thus, the aim of this study was to assess the palatability of cat food with application of sodium pyrophosphate and/or yeast extract, alone or in combination over the kibbles.

The experiment was conducted in the cattery of the Centro de Tecnologia Animal Ltda (CTA; Domingos Martins, ES, Brazil). Twenty healthy adult mongrel cats (10 male and 10 female) were used, with known body condition (score: $3.3 \pm 0.3$ ), weight $(3.7 \pm 0.45 \mathrm{~kg})$, and age $(3.4 \pm 0.86$ years). The cats were kept in a room (temperature: $21.2 \pm 2.3^{\circ} \mathrm{C}$; humidity:
$55 \pm 3.5 \%)$ and housed individually in galvanized steel cages $(90 \times 90 \times 100 \mathrm{~cm})$ containing a sandbox and a suspended shelf where the cat could sleep.

In the preparation of the experimental diets, a basal food (control) without palatant (Table 1), and three others with external application of sodium pyrophosphate $(0.3 \%)$; yeast extract $(0.2 \%)$, and blend $(0.5 \%$; yeast extract: sodium pyrophosphate: 40:60) were used.

Poultry fat $(3 \%)$ was added inside the rotatory mixer $(5 \mathrm{~min})$ before the palatant additives were applied to coat the kibbles to promote a greater adhesion of the powder palatant particles to kibbles. In order to improve distribution of palatant additives, which are in the form of a fine powder, a fine sieve (hole diameter: $0.8 \mathrm{~mm}$ ) was used during their application to manually spread them directly onto the food. The same amount of poultry fat was also included in the basal food to maintain the food preparations isoenergetic.

Table 1 - Ingredients and chemical composition of food.

\begin{tabular}{|c|c|}
\hline Ingredients & Weight ( $\mathrm{g} \mathrm{kg}^{-1}$ of dry matter) \\
\hline Corn & 250 \\
\hline Poultry by product meal & 245 \\
\hline Soy bean meal & 165 \\
\hline Rice & 150 \\
\hline Corn gluten meal 21 & 150 \\
\hline Corn gluten meal 60 & 20.0 \\
\hline Micronized whole soybean & 7.50 \\
\hline Vitamin Mineral Premix ${ }^{1}$ & 4.00 \\
\hline Choline chloride $(60 \%)$ & 3.50 \\
\hline Common salt & 2.50 \\
\hline Calcium propionate & 1.00 \\
\hline L-Taurine & 0.85 \\
\hline Butylated hydroxytoluene (BHT) & 0.10 \\
\hline \multicolumn{2}{|c|}{ 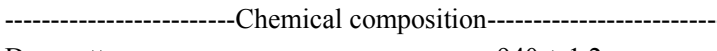 } \\
\hline Dry matter & $940 \pm 1.2$ \\
\hline Crude protein & $315 \pm 2.3$ \\
\hline Crude fiber & $20.2 \pm 0.3$ \\
\hline Crude fat (acid ether extract) & $105 \pm 0.8$ \\
\hline Ash & $85 \pm 0.4$ \\
\hline Calcium & $19.8 \pm 0.2$ \\
\hline Phosphorous & $12.4 \pm 0.1$ \\
\hline Metabolizable energy (kcal) & 3450 \\
\hline
\end{tabular}

Additives $\left(\mathrm{kg}^{-1}\right)$ : Copper: 4300mg; Iron: 23000mg; Manganese: 1880mg; Zinc: 40000mg; Iodine: $300 \mathrm{mg}$; Selenium: $50.0 \mathrm{mg}$; Folic acid: $300 \mathrm{mg}$; Pantothenic acid: $3000 \mathrm{mg}$; Biotin: $25.0 \mathrm{mg}$; Choline: 300mg; Niacin: 15.0mg; Pyridoxine: 1500mg; Riboflavin: 1500mg; Thiamine: 5000mg; Vitamin A: 2700KUI; Vitamin $\mathrm{B}_{12}$ : 40.0mg; Vitamin $\mathrm{D}_{3}$ : 240KUI; Vitamin E: 40.0KUI; Vitamin K: 1200mg. 
Cats' preferences were determined using the two-bowl method, and food relative consumption (\%) was calculated as a fraction of the total food consumed by using the formula: Relative consumption $(\%)=$ Food A consumption (g) x 100 / Food A+B consumption (g). In each preference test, the food pairs were given alternating between right and left, being placed at the same time in amounts $20 \%$ higher than those recommended by the NRC (2006) for adult cats $(100 \mathrm{x}$ body weight ${ }^{0.67}$ ). Six food pairs were assessed for cats' preferences: (1) control x pyrophosphate; (2) control $\mathrm{x}$ yeast extract; (3) pyrophosphate x yeast extract; (4) blend x control; (5) blend x pyrophosphate, and (6) blend $\mathrm{x}$ yeast extract. Consumption of the tested diets was evaluated in duplicate in two consecutive days and bowls were left with the animals for $24 \mathrm{~h}$. At the end of each test, 40 observations ( 20 cats; 2 days) were obtained. Water was provided ad libitum throughout the entire study period.

The data thus obtained were analyzed using parametric statistics. Consumption percentages were transformed to arcsine square root and then compared as independent variables using the Student's $t$-test
(5\% probability). The Statistical and Genetic Analysis System (SAEG, v. 9.1; Viçosa, MG, Brazil) was used.

Application of $0.5 \%$ of the blend (sodium pyrophosphate plus yeast extract) to the food promoted an increase in cats' preference $(\mathrm{P}<0.05)$, as compared to control. In addition, the blend was able to stimulate cats' preference more than yeast extract alone (Figure 1).

The ability to detect taste is given by gustatory receptors, which are present in the tongue. They can respond positively or negatively to stimuli caused by the food. In cats, the T1R1/ T1R3 amino acid receptors can be stimulated by certain amino acids (BRADSHAW, 2006) and also by pyrophosphate (BRAND \& BRYANT, 2012). Stimulation of gustatory receptors with amino acids or pyrophosphate was observed in a study with intracellular markers, and increased intracellular calcium was released as a response to the presence of pyrophosphate or amino acids (lysine, proline, and alanine). However, this effect on the feline receptor T1R1/T1R3 was higher when pyrophosphate was combined with these

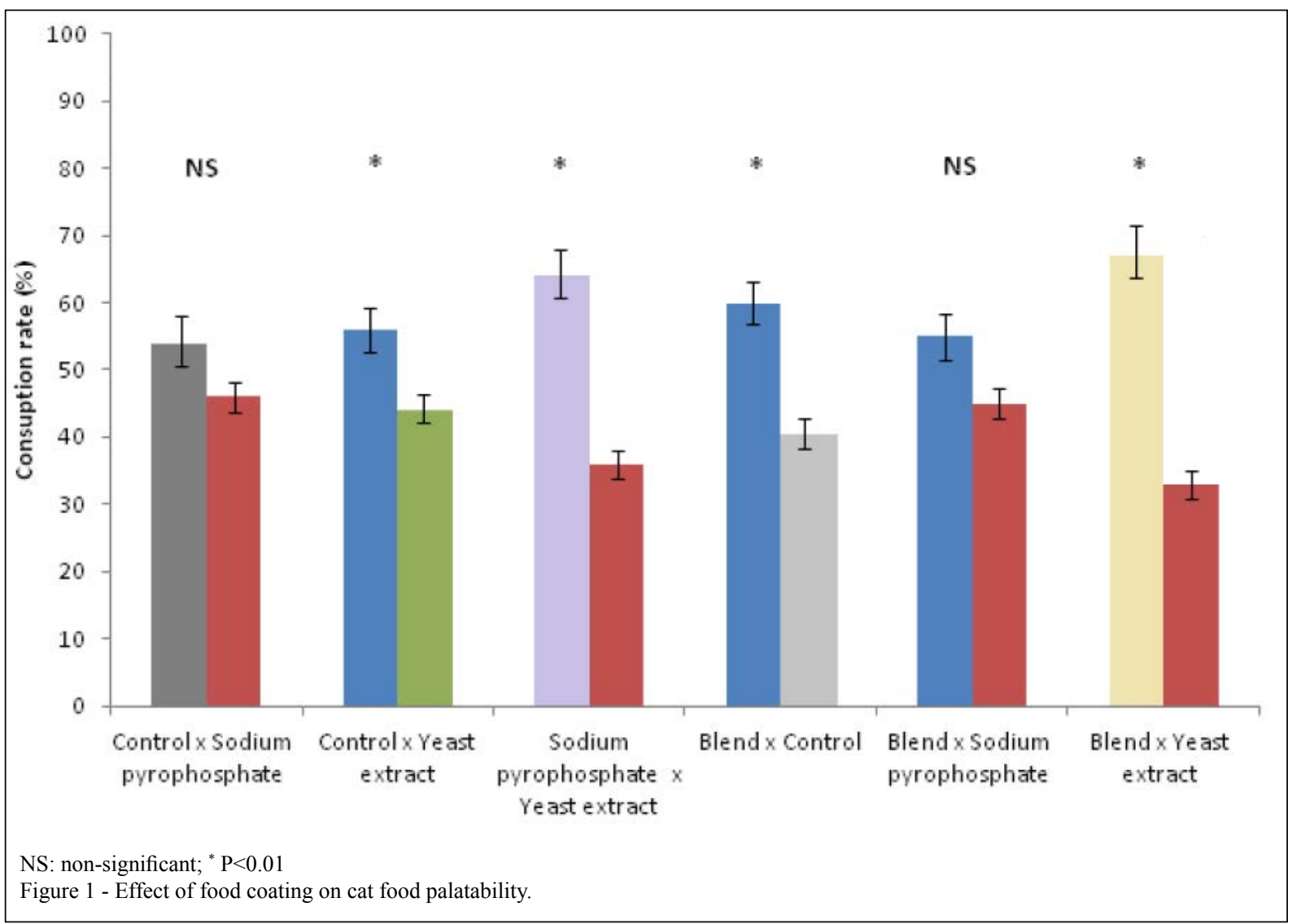

Ciência Rural, v.46, n.12, dez, 2016. 
amino acids, and a synergistic effect was observed (BRAND \& BRYANT, 2012).

The positive result observed with use of blend was probably due to the presence of both free amino acids and nucleotides contained in the yeast extract, which, in combination with pyrophosphate, promoted a greater response of the gustatory receptors T1R1/T1R3. Taste after consumption of a specific amino acid can be intensified by interaction with phosphate compounds, in which this association stimulates receptors responsive to presence of isolated pyrophosphate or a particular amino acid (BRAND \& BRYANT, 2012).

\section{BIOETHICS AND BIOSSECURITY COMMITTEE APPROVAL}

The experimental protocol was approved by the Ethics Committee (CEUA-CTA: 127/2014).

\section{ACKNOWLEDGEMENTS}

The first author is grateful for the scholarship granted by the Fundação de Amparo à Pesquisa e Inovação do Espírito Santo (FAPES). We also acknowledge Nutriave Alimentos ${ }^{\circledR}$ for their help in the production of experimental diets and Centro de Tecnologia Animal for the financial support for the study.

\section{REFERENCES}

BRADSHAW, J.W.S. The evolutionary basis for the feeding behavior of domestic dogs (Canis familiaris) and cats (Felis catus). Journal of Nutrition, v.136, n.7, p.1927S-1931S,
2006. Available from: <http://www.ncbi.nlm.nih.gov/pubmed>. Accessed: Mar. 10, 2015.

BRADSHAW, J.W.S. et al. Food selection by the domestic cat, an obligate carnivore. Comparative Biochemistry and Physiology, v.114, n.3, p.205-209, 1996. Available from: <http://www.ncbi. nlm.nih.gov/pubmed $>$. Accessed: Mar. 11, 2015.

BRAND, J.; BRYANT, B. Cats' preference for pyrophosphates and search for a feline taste receptor using molecular biology. Philadelphia, USA: Monell Chemical Senses Center, 2012. 6p. (Scientific Release).

MACDONALD, M.L. Nutrition of the domestic cat, a mammalian carnivore. Annual Review of Nutrition, v.4, p.521-562, 1984. Available from: $<$ http://www.annualreviews.org $>$. Accessed: Mar. 20, 2015. doi: 10.1146/annurev.nu.04.070184.002513.

NATIONAL RESEARCHCOUNCIL(NRC). Nutrient requirements of dogs and cats. Washington, D.C.: National Academies, 2006. 398p.

OGOSHI, R.C.S. et al. Acidifying and yeast extract in diets for adult cats. Animal Science Journal, v.85, n.5, p.555-561, 2014. Available from: $<$ http://onlinelibrary.wiley.com>. Accessed: Apr. 06, 2015. doi: 10.1111/asj.12166.

TESHIMA, E. et al. Yeast extract fed to dogs: digestibility and palatability. In: ANNUAL MEETING OF BRAZILIAN ANIMAL SCIENCE SOCIETY, 44., 2007, Jaboticabal, SP. Proceedings... Jaboticabal: SBZ, 2007.p.3-5.

UNIVERSIDADE FEDERAL DE VIÇOSA (UFV). Sistema de análises estatísticas e genéticas - SAEG. Versão 9.1. Viçosa, MG, 2007. 59p.

ZAGHINI, G.; BIAGI, G. Nutritional peculiarities and diet palatability in the cat. Veterinary Research Communications, v.29, Suppl.2, p.39-45, 2005. Available from: <http://www.ncbi.nlm.nih.gov>. Accessed: Mar. 21, 2015. doi: 10.1007/s11259-005-0009-1. 